Claremont Colleges

Scholarship@ Claremont

All HMC Faculty Publications and Research

HMC Faculty Scholarship

8-1-2009

\title{
Institutional Resilience Amid Political Change: The Case of Biodiversity Conservation
}

Paul F. Steinberg

Harvey Mudd College

\section{Recommended Citation}

Steinberg, Paul F. (2009) "Institutional Resilience amid Political Change: The Case of Biodiversity Conservation." Global Environmental Politics 9(3):61-81.

This Article is brought to you for free and open access by the HMC Faculty Scholarship at Scholarship @ Claremont. It has been accepted for inclusion in All HMC Faculty Publications and Research by an authorized administrator of Scholarship @ Claremont. For more information, please contact scholarship@cuc.claremont.edu. 


\section{PROJECT MUSE}

\section{Institutional Resilience Amid Political Change: The Case of Biodiversity}

Conservation

Paul F. Steinberg

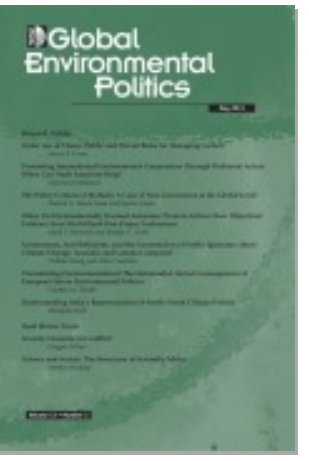

Global Environmental Politics, Volume 9, Number 3, August 2009, pp. 61-81 (Article)

Published by The MIT Press

$\Rightarrow$ For additional information about this article http://muse.jhu.edu/journals/gep/summary/v009/9.3.steinberg.html 


\section{Institutional Resilience Amid Political Change: The Case of Biodiversity Conservation}

Paul F. Steinberg

One of the distinctive features of environmental protection as a political problem is the challenge that it poses for institutional design. Within political science, considerable attention has been focused on the mismatch between the geographic scope of environmental problems and the spatial jurisdiction of the institutions responsible for their management. At the international level, for example, transboundary pollution problems require novel forms of coordination among sovereign nations in the absence of an international government, ${ }^{1}$ while domestically cross-jurisdictional spillover effects have been the focus of innovative policy efforts and related research on regional environmental management and interagency cooperation. ${ }^{2}$ More generally, research on multi-level governance is motivated to a significant degree by a recognition that environmental problems require institutional responses that operate on multiple geographic scales. $^{3}$

Whereas spatial scales have received significant attention from those concerned with institutional design, comparatively little attention has been devoted to the mismatch in temporal scales between the long-term requirements of environmental management and the short time horizons governing public and private decisions affecting the environment. The literatures on institutional resilience and common property regimes, ${ }^{4}$ which have taken the lead in nudging analysts to consider the longue durée, have been remarkably silent on questions of politics, reducing questions of institutional design to the efficient acquisition of ecological knowledge, flexible management in the face of uncertainty, and the design of rules governing resource appropriation. These approaches overlook essential components of environmental protection in practice, such as power, social mobilization, and competing (and evolving) social values. Although advocacy and mobilization are sometimes implied in these discussions,

1. Young 1994.

2. Margerum 2008; Johnson et al. 1999; and Thomas 2003.

3. Bulkeley 2005; and Young 2002.

4. Olsson et al. 2004; and Dietz et al. 2003.

Global Environmental Politics 9:3, August 2009

๑ 2009 by the Massachusetts Institute of Technology 
the political underpinnings of long-term environmental management remain poorly understood.

This analysis aims to bring politics back into the institutional design equation, with a focus on the creation of resilient institutions for the long-term conservation of biological diversity. ${ }^{5}$ Biodiversity is an illuminating test case for institutional responses to long-term policy problems because the natural processes at risk (the survival of species and ecosystems) require very long-term social stewardship, the absence of which may produce irreversible losses in social welfare, insofar as these biological resources are valued by society for their inherent worth and for the goods and services they provide. Moreover, while survey data show high levels of public concern over species loss in a wide range of societies, ${ }^{6}$ in practice the political deck is often stacked against biodiversity conservation because the decisions governing land use and harvesting rates often weigh concentrated short-term private costs against diffuse long-term public goods. ${ }^{7}$ The cumulative result is that between 12 percent and 52 percent of species within well-studied higher taxa worldwide are currently threatened with extinction. ${ }^{8}$ The stakes are high, the politics are uncertain, and the resources at risk are highly vulnerable to social change, presenting serious challenges for institutional design.

In the first part of this article I contrast the long-term requirements of biodiversity conservation with the pervasive changes in social conditions, institutions, and political preferences that influence conservation outcomes. I then introduce a new approach to biodiversity conservation-conservation systems - that entails the deliberate design of a network of interlocking institutions and associated political constituencies capable of providing a resilient safety net to prevent irreversible declines in biodiversity at a given site. I argue that the conservation systems approach offers valuable diagnostic and prescriptive tools for the management of this long-term policy problem.

\section{Conservation in the Face of Stochastic Social Change}

Biodiversity conservation has been recognized as a legitimate policy priority at the highest political levels, most notably by the 168 signatories to the Convention on Biological Diversity, which highlights the value of biodiversity as both a source of ecosystem services and an inherently important part of our Earth's natural heritage. In practice, however, biodiversity conservation poses a special challenge for political institutions for at least three reasons. First, in contrast to

5. Biological diversity, or biodiversity, refers to natural variety in ecosystems, species, and genes. Biodiversity conservation denotes nature conservation with a special emphasis on preventing irreparable harm to natural diversity through species extinction or the destruction of unique ecosystems. For an overview see Steinberg 1998.

6. Dunlap et al. 1993.

7. Tobin 1990.

8. Millennium Ecosystem Assessment 2005. 
decision-making processes surrounding many environmental problems, shortterm changes in land use decisions and regulatory regimes can have irreparable consequences due to the irreversibility of extinction. As a consequence, biodiversity conservation requires institutional responses that are not only long lasting but are capable of maintaining diligence against short-term reversals. Second, in contrast to an issue like stratospheric ozone depletion, for which a small number of chemicals are responsible for the harm, ecosystems and species are vulnerable to a wide array of human activities. Even climate change, which results from diverse economic activities, is mediated through the impacts of a small number of substances (notably carbon dioxide and methane) that can be reduced in a relatively permanent sense through technological alternatives. With biodiversity loss, in contrast, the problem is never truly "solved."

While it is true that most major institutional innovations require a longterm commitment, a third characteristic distinguishing biodiversity conservation from many policy issues is the extraordinarily long time horizon that one must keep in mind, given the time scales intrinsic to ecological concerns. A single sea turtle may require half a century just to reach sexual maturity; the assemblages of species found in relatively undisturbed ecosystems are the product of evolutionary processes spanning millions of years.

The long-term requirements of biodiversity conservation stand in sharp contrast to the scope and pace of social change in contemporary societies. Conservation institutions, when they endure, must do so in a context of pervasive political, economic, and cultural change and associated institutional turnover. Most of the world's countries are variously prone to disruptions from rapid economic growth, runaway inflation, economic collapse, wildly fluctuating export earnings, ethnic conflict, civil wars, revolutions, coups, bureaucratic turnover and associated policy churning, and unprecedented rates of population growth and urbanization. ${ }^{9}$ These phenomena occur alongside cross-national trends such as democratization (which often produces highly unstable transitional regimes), privatization, globalization, regional integration, new levels and types of social mobilization, and decentralization of natural resource management, which has taken place in an estimated 60 developing countries. ${ }^{10} \mathrm{In}$ this context, conservation institutions must achieve what Clemens and Cook call "reliable reproduction in the face of stochastic change."

Even in times of political stability, public support for policy goals can fluctuate wildly. ${ }^{12}$ The problem of consistent public support is especially acute for biodiversity. On the one hand, few would advocate the disappearance of a significant swath of all forms of life on Earth, the permanent transformation of rare landscapes and ecosystems, and the loss of the associated social value. Yet as was noted earlier, because conservation typically provides diffuse long-term

\footnotetext{
9. Steinberg 2008.

10. Ribot 2002.

11. Clemens and Cook 1999, 448.

12. Downs 1972.
} 
public benefits while imposing concentrated near-term costs on a few actors, it is often difficult to ensure a consistent response to defend the public interest in this arena. Moreover, biodiversity is often poorly understood (most species have not even been named), its value is difficult to quantify and capture through market mechanisms, and species habitats are often highly site-specific and therefore susceptible to rapid destruction by a small number of actors.

In sum, efforts directed toward the long-term conservation of biological diversity in the face of pervasive social change must contend with three unique challenges: the irreversibility of extinction, which requires a robust safety net to prevent irreparable harm; diverse and interacting threats to ecosystems, which dictate against piecemeal approaches; and the tenuous nature of political support for conservation, which suggests that efforts to create resilient institutions must take into account strategies for the mobilization of political constituencies. This leaves us with two analytic tasks. The following section provides an operational definition of institutional resilience founded on the idea of sustaining a mission over time, and argues that research on common-pool resources has paid inadequate attention to the normative and political dimensions of institutional effectiveness. The remainder of the article then describes how conservation systems represent a practical, politically explicit planning approach for the design of long-term institutional responses.

\section{Creating Resilient Institutions}

How can we create socially agreed-upon rules governing the long-term use and conservation of biodiversity when ongoing change is one of the defining characteristics of modern society? A critical part of the answer concerns the quality and characteristics of the institutions we design to address long-term problems. Over the past decade, international environmental and development organizations have taken a growing interest in the role of effective institutions and governance in promoting sustainable development. ${ }^{13}$ There is a growing recognition that the institutional rules of the game exercise a strong-and often determinative-influence on the provision of public goods and the possibility for achieving economic growth, poverty alleviation, civil society development, sustainable resource extraction, and pollution reduction, among other social goals.

The relationship between institutional design and long-term policy problems is not merely incidental because institutions are by definition oriented toward the production of relatively durable patterns of social interaction. A crucial part of the design task is to ensure enough adaptability to allow the institution to retain its relevance and efficacy in changing external environments. The stability and adaptability dimensions of institutional design are captured by the concept of institutional resilience. Researchers associated with the Resilience Alliance have applied this idea broadly as a metaphor to describe the capacity of

13. See for example World Bank 2003; and Akella and Cannon 2004. 
social-ecological systems to "absorb shocks and still maintain function" in "changing environments where the future is unpredictable and surprise is likely." ${ }^{14}$ For the present purpose, an institution is resilient to the extent that it maintains its effectiveness over time despite changing external conditions. Effectiveness denotes the extent to which the institution fulfills the core mission envisioned by its founders. An institutional arrangement may therefore demonstrate resilience even if its specific rules, organizational components, and strategies shift over time, so long as it continues to fulfill this mission. Likewise, an institutional arrangement may perish if its mission is fundamentally altered, even if its operational machinery (procedures, budget, staff, infrastructure) persists.

This emphasis on sustaining a mission, or foundational norm-such as a normative orientation toward the conservation of biological diversity-has received insufficient attention from political scientists studying institutional stability. In what is probably the most influential work by a political scientist on the topic of long-term environmental management, Ostrom reviews numerous case studies of communities that have crafted long-lasting local institutions for sustainably managing resources such as water, forests, and fisheries. ${ }^{15}$ On this basis she devises a list of characteristics associated with durability, such as clear rights of access to resource use, low-cost monitoring, graduated sanctions, conflict resolution mechanisms, and venues for collective choice. ${ }^{16}$ A serious limitation of this approach, however, is that it focuses entirely on the machinery of longevity but not the principle to be sustained. Ostrom's work is clearly motivated in part by a concern for sustainability, but she only examines the factors that caused these environmental institutions to last. Ostrom does not ask what caused them to remain committed to sustainable resource use-why do some long-lasting institutions continue to protect the environment, while others turn their resilient capacities to other social goals, like the rapid liquidation of natural assets for the purpose of industrial expansion?

To sustain the normative commitment at the heart of an institution requires a resilient social constituency advocating on behalf of that norm and its associated institutional arrangements. Yet social mobilization is rarely featured in the literature on common-pool resources. This may be a consequence of the methodological individualism underpinning much of this literature, which relies heavily on rational choice approaches to institutional analysis. One of the great strengths of the approach is its synthesis of case material with systematic analyses of the cost-benefit calculations made by decision-makers subject to a given set of resources and rules. What this leaves out is a fuller account of politics, one recognizing that individuals are not merely economic actors, that preferences are socially constructed, and that institutions reflect, reinforce and/or reorder power relations. ${ }^{17}$

Among the shortcomings of analyzing institutional resilience through a

14. Folke 2006, 253-54; see also Janssen et al. 2006.

15. Ostrom 1990.

16. See also Ostrom et al. 2002.

17. For a similar critique see Agrawal 2003, 256-259; see also Hall and Taylor 1996. 
cost-benefit lens, two stand out. First, this approach misses the diverse motivations underpinning pro-environment behavior. While it is certainly true that price signals and economic sanctions and rewards shape behavior regarding the environment, the value that people derive from nature comes also from aesthetic, educational, scientific, recreational, nationalistic, religious, and diverse ethical considerations. This is true in poor societies as well as in wealthy ones. ${ }^{18}$ The mobilization of environmentalist Buddhist monks in Thailand, efforts to protect scenic Victoria Harbor in Hong Kong, the March for Territory and Dignity by indigenous peoples in the Bolivian Amazon-these realities beg for a richer explanation of the social underpinnings of environmental behavior. There are diverse constituencies for (and against) the environment as well as diverse motivations on the part of any given actor. Research on pro-environment behavior within the private sector, for example, reveals that the farmers who adopt organic agriculture are driven largely by their normative commitments to environmental goals. ${ }^{19}$ Institutional design must be approached with these diverse motivations in mind, to avoid relying on a thin social constituency whose motivation is purely financial and to instead build a thick social safety net comprised of diverse conservation constituencies.

A second reason why we must move beyond an overly economistic interpretation of environmental behavior is that this perspective ignores the role of political mobilization in protecting the environment. It is axiomatic among scholars and practitioners alike to assert that if we wish to change the activities of resource users to provide public goods like standing forests, society must create mechanisms to compensate them..$^{20}$ But there are two dimensions to these actors' behavior. The first is a change in economic behavior, such as the farmer who leaves trees standing in response to a government incentive program. The second component is the farmer's role as a political actor. If a threat to the government program emerges, that person may well voice objections, organize, advocate, and be heard. In Hirschman's terms, these actors not only "exit" environmentally destructive practices through their economic choices, but also "voice" to support rules that they find beneficial for economic and/or other reasons. ${ }^{21}$ The decision facing these decision-makers is not merely which resources to exploit or rules to follow, but whether to advocate through political channels for the survival of the institutional arrangement itself. The political mobilization of rubber tappers in the Brazilian Amazon, of the Greenbelt movement in Kenya, of US organic farmers in advocating rigorous labeling standards, and of Dupont Corporation in pushing for agreement on the Montreal Protocol on Substances That Deplete the Ozone Layer, are telling in this regard. By focusing greater analytic attention on the political characteristics of these socalled "economic actors" - their behavior, identities, resources, strategies, and

18. Steinberg 2001, 153-191.

19. Fairweather 1999.

20. Pearce 1991.

21. Hirschman 1970. 
opportunities-we not only arrive at a richer understanding of environmental politics in practice, but can devise new criteria for institutional design, implementing measures that will attract a mix of constituencies likely to be politically influential over the long haul.

Building on this perspective, in the next section I describe a politically explicit analytic approach that can be used to diagnose the resilience of conservation institutions and to highlight opportunities for institutional strengthening.

\section{Designing Conservation Systems}

Environmental managers have long advocated more comprehensive approaches to protecting biodiversity ${ }^{22}$ but there has emerged little guidance on how to put such a perspective into practice. Here I propose a new approach-conservation systems-as a potentially powerful method for doing so, focusing on criteria for ensuring institutional resilience to guard against irreversible losses of biodiversity over long time horizons. A conservation system is a constellation of actors, organizations, and regulations oriented toward the protection of valued biological resources at a particular site. These biological resources could be as specific as a local population of a rare species, or could include a representative example of a regionally disappearing plant community, or comprise an entire forest, coral reef, or otherwise biologically important landscape that is valued for any number of reasons, from the provision of fuel wood to respite for urban dwellers, the protection of watersheds, fish and game habitat, scenic vistas, recreation, research and education, or other values.

The term "system" as used here corresponds to Rogers' definition of a social system as "a set of interrelated units that are engaged in joint problem solving to accomplish a common goal." ${ }^{23}$ In practice, a core group of conservation proponents would bring together potentially interested parties, agree on the valued biological resources of concern, and engage in a collective diagnostic and planning exercise. As a diagnostic tool, the conservation systems approach offers environmental planners and concerned citizens a methodology to systematically assess the existing, de facto safety net-the regulatory structures, organizations, and constituencies likely to act on behalf of these resources-and analyzes its likely resilience in the face of future political and economic disruptions. Conservation systems thus respond to Robert Lempert's call for "strategies that are robust in the face of an unpredictable future." ${ }^{24}$ As a planning tool, this approach encourages conservation proponents to explicitly design such a system, filling gaps and reaching out to diverse constituencies, thereby deepening social understanding of, and support for conservation.

As a proposal for a novel approach to conservation planning, the discus-

22. Johnson 1999.

23. Rogers 1995, 23.

24. Lempert 2000, 388. 
sion to follow is necessarily speculative. Its realism derives from the fact that many of the components of conservation systems are already in place. There are innumerable efforts underway around the world at collaborative management of regional and local landscapes that involve diverse stakeholders at different levels of governance in joint problem solving. Sometimes these are at the instigation of national regulatory agencies, as with India's Joint Forestry Program or the US National Estuary Program. Other times they are regional initiatives such as Natural Communities Conservation Planning in Southern California or the Mesoamerican Biological Corridor. International organizations such as UNESCO's Man and the Biosphere Program devote considerable resources to community-based collaborative conservation planning, as do NGOs such as the Worldwide Fund for Nature. The proliferation of groups focused on regional watershed management, collaborative rangeland management, communitybased coastal management, and similar arrangements across a wide range of policy areas has spawned a large research literature in public administration tracking their characteristics, prerequisites, and effects. ${ }^{25}$ These arrangements all entail cooperation among diverse stakeholders in place-based decision-making and planning processes. So there is ample precedent for collaborative conservation planning, and indeed conservation systems would often be incorporated into ongoing planning processes and existing collaborative networks.

The distinctive feature of the conservation systems approach is its focus on long-term resilience in the face of change, and its explicit emphasis on constituency building and political advocacy. Conservation systems should be designed to withstand short-term perturbations such as inflation, recessions, boom-andbust cycles associated with particular industries, institutional instability, political crises, and variation in the priorities and capabilities of conservation advocates. To achieve the necessary resilience, conservation systems should include constituencies at multiple scales (local, regional, national, and where possible international) and across multiple political parties, and should build support within diverse sectors of society for which fluctuations in support are unlikely to move in tandem.

Before describing these design criteria in greater detail, two clarifications are in order. First, the conservation systems approach does not assume or require the mobilization of all relevant actors along these various axes of diversity. The goal is to more effectively coordinate the activities of those already sympathetic to the conservation of the biological resources in question, and to increase awareness of and support for this goal in the broader community. Nor does this approach, with its single-minded focus on biodiversity, presume that these actors will (or indeed should) seek to promote conservation above all other social goals in all places. Conservation systems should be designed with respect to specific resources with high conservation value, not the landscape as a whole. Moreover, the most serious threats to biodiversity seldom result from 
projects that are vital to human welfare or economic development and for which no plausible project alternatives exist. An effectively organized conservation system can serve a "stop and think" function equivalent to environmental impact assessment, promoting public deliberation among diverse interests and preventing premature closure on a decision that could be improved with more careful consideration of the long-lasting environmental consequences. A conservation system can coordinate public education and policy advocacy and can improve compliance with existing environmental regulations.

\section{Diversity across Scales}

A resilient conservation system is one that can withstand social change without irreparable harm to the biological resources it is designed to protect. An important design criterion, therefore, involves the creation of constituencies at multiple levels of governance. In other words, the spatial design considerations highlighted at the outset of this article reappear in the service of temporal management.

It has been widely noted in the literature that when protected areas are established in a manner that disregards or even disenfranchises local constituencies, they can become a source of fierce contention, compromising both conservation and development goals. ${ }^{26}$ Unlike many other types of long-term policy challenges, such as central banking or pension administration, the site-specific nature of biological diversity requires support from innumerable local communities. In California, for example, the majority of rare and endangered plant species occur in only one or two local counties and nowhere else, meaning that one local community with practices unfavorable to conservation can cause a species to permanently disappear from the stock of global biological diversity. ${ }^{27}$ Moreover, if political change at the national level puts in place officials who are unsympathetic to conservation goals, it is wise to have a strong local constituency whose support can serve as a buffer against irreversible damage from shortsighted decisions by national policy-makers. ${ }^{28}$

There are many proven methods for thickening a social safety net in support of biodiversity to include local constituencies. The approaches are diverse and depend on local conditions, but examples include grassroots campaigns to build local awareness of endangered species, such as the successful campaign to protect the St. Lucia Parrot using a social marketing methodology subsequently replicated in dozens of developing countries; ${ }^{29}$ locally initiated protected areas, such as Gran Chaco National Park in Bolivia; community development projects that rely on intact ecosystems, such as the marketing of non-timber forest products; payment for ecosystem services, such as the Costa Rican program that pays

26. Western and Wright 1994.

27. Press et al. 1996

28. Examples of fluctuating national support are numerous. See Steinberg 2008.

29. See www.rareconservation.org. 
farmers to leave trees on their property; and trail building and nature interpretation to encourage local awareness of spectacular landscapes.

Conversely, any strategy relying exclusively on local support runs the risk that a change in local leadership, economic conditions, or short-term preferences will lead to destruction of the resource. Although an overwhelming majority of citizens may express a genuine concern for habitat conservation, they may act quite differently when faced with the possibility of foregoing tangible local benefits for the sake of one or a small number of species. From a local perspective it often appears that significant benefits (timber revenues, industrial expansion, new housing, recreational opportunities) are sacrificed for the benefit of an obscure desert flower or small fish; meanwhile, from a bird's eye view, social value is depleted flower by flower, animal by animal, across the planetary landscape, leading to a situation that deviates sharply from public preferences. It is at the local level that this "tyranny of small decisions" 30 is felt most forcibly; not surprisingly, even strong advocates for democratic decentralization of natural resource management, such as Ribot, recommend that national authorities establish baselines to ensure environmental protection. ${ }^{31}$ Resilient conservation systems must therefore include national-level constituencies and institutions that are buffered from short-term cost calculations at the local level.

A useful (and still underutilized) technique for building political support among high-ranking politicians at the national level was pioneered by Thomas Lovejoy of the Smithsonian Institution and has been developed more systematically by the Organization for Tropical Studies. With this approach, influential decision-makers are selectively invited to nature retreats that include lectures from environmental experts, field trips, and open-ended discussions of natural resource policy and management. ${ }^{32}$ When implemented in an open manner that encourages discussion and debate, this model has proven to be an effective tool for building an interest in conservation among political sovereigns. ${ }^{33}$

Between the local and national levels, state or provincial constituencies can add yet another voice to ensure that short-term changes at one level of governance do not result in irreversible losses in biological diversity. Examples include Brazil's Ecological Goods and Services Tax, adopted by nine Brazilian states to encourage biodiversity conservation at the municipal level. In some cases it is also possible to attract significant attention at the international level, lending yet another layer of resilience to a conservation system. International constituencies can play an important stabilizing role because their support is buffered from many of the social disruptions affecting domestic components of the system, such as runaway inflation or a crackdown on autonomous social organizations. Examples include the emergency response unit of the World Conservation Monitoring Centre, UNESCO's emergency assistance for World Heritage properties, and a range of initiatives by The Nature Conservancy to provide

30. Odum 1982.

31. Ribot 2002.

32. The Latin America Decision Makers course is described at http://www.ots.ac.cr.

33. Steinberg 2001. 
funds for ailing protected areas systems. International constituencies can be brought into the conservation system through purchasing contracts (e.g. pharmaceutical prospecting agreements or international markets for shade-grown coffee), climate change mitigation projects, educational exchanges, research collaborations, tourism, designations of globally significant areas, and NGO project support.

Notwithstanding the benefits of multi-level coordination, these efforts can be difficult to initiate and sustain because professional and cultural norms and routines lead conservation advocates to specialize in one or another level of governance. There are, however, special categories of individuals comfortable operating at more than one level of governance. Advocates bridging domestic and international policy arenas ${ }^{34}$ or navigating from local to national levels ${ }^{35}$ can facilitate coordination across levels of the conservation system. This bridging function may be institutionalized in formal "boundary organizations" that take the form of "task forces, design teams, rule-making bodies, coordinating committees, study commission[s], centers, networks, and other similar entities that are charged with reflecting diverse information and intelligence in the service of some task or action that is not possible for one actor or perspective to perform alone." 36

\section{Support from Multiple Political Parties}

To ensure a resilient social constituency for conservation, it is essential to cultivate sympathetic contacts in diverse political parties. In the course of interviews with environmental policy reformers from dozens of developing countries over the past decade, I have observed a strong tendency to shun multi-partisanship. However, concentrating one's hopes, resources, and personal contacts in a single political party carries significant risks. In societies characterized by rapid political turnover, partisan environmentalism produces a series of fits and starts for conservation that lack the long-term support across diverse political administrations-governance across governments-that is needed for cumulative institution building. ${ }^{37}$ If instead conservation proponents cultivate contacts in diverse political parties, this increases the number of access points to elected bodies such as legislatures and city councils and hedges political bets in the face of unpredictable changes in political administrations. Costa Rica's institutional successes in biodiversity conservation owe much to the fact that the country's environmental reformers have gone to great lengths to cultivate ties in both major political parties, and there are important strategic alliances among top-ranking environmental officials across the two parties. ${ }^{38}$

What techniques exist for building multi-party coalitions in support of

34. Steinberg 2003.

35. For examples see Krishna 1991; and Hahn et al. 2006.

36. Feldman et al. 2006, 95.

37. Steinberg 2008.

38. Steinberg 2001. 
conservation? This important question has not managed to attract systematic attention from political scientists beyond analyses of the strategic dilemmas facing green parties. ${ }^{39}$ Indeed, the role of political parties in environmental policymaking has not, to my knowledge, been studied systematically in any developing country. Anecdotally, however, there are some promising findings. The use of conservation education retreats for high-ranking officials, described earlier, has produced important multi-party collaborations in Latin America. In Costa Rica, one such retreat resulted in a successful effort to amend the national constitution to guarantee every citizen's right to a healthy environment. Bolivian policy reformers closely studied the methodology used in Costa Rica and organized a retreat for lawmakers to showcase community-based sustainable forestry projects, building multi-partisan support for one of the world's most progressive sustainable forestry laws in $1996 .{ }^{40}$ Lower-profile initiatives to build support across the political spectrum could include deliberately staffing the governing boards of conservation organizations with dedicated members from diverse political parties, and using political affiliation as one criterion for deciding which local communities to include in a pilot project.

\section{Diversity across Social Sectors}

To ensure that a conservation system can endure in a context of social change requires the cultivation of constituencies from diverse sectors of society. Relevant axes of sectoral diversity include nonstate versus government actors, private sector versus nonprofit organizations, and diverse categories of market activities, such that income streams from conservation-related activities are unlikely to respond equally to a given shift in economic conditions. Sectoral diversity can serve as one criterion for the type of projects pursued in connection with a protected area, as conservation system proponents identify missing categories of social constituencies and pursue projects that will attract their participation. Similar considerations can guide decisions regarding the focus of public education and outreach efforts.

A social constituency for biodiversity is especially important because civil society organizations are often key components in the institutional network responsible for protecting species and ecosystems and their associated social benefits. Civil society organizations play a leading role in a wide range of conservation activities such as land purchases, legal advocacy, education, operation of nature reserves, tourism, wildlife population monitoring and database management, and passage of local open space ordinances ${ }^{41}$ Collaborations between government conservation agencies and civil society organizations are commonplace around the globe, and the effectiveness of conservation policies relies to a

39. O'Neill forthcoming.

40. Steinberg 2001.

41. Koontz and Thomas 2006; and Press 2002. 
significant degree on civic engagement. ${ }^{42}$ For biodiversity, as with many other environmental issues, "policy" is not so much a government activity as it is a course of social action in which government plays a central role. Resilient conservation institutions thus require resilient social constituencies.

Creating interest on the part of both civil society and governmental actors increases the odds that the inevitable fluctuations of interest or engagement by one sector may be tempered by the other. Thus a national park benefits from having civil society constituencies who can publicly promote the park's goals and, in the event of threats to the park, can mobilize the public to bolster the position of conservation officials vis-à-vis their opponents. Conversely, bolstering nongovernmental conservation efforts through constructive government involvement-such as tax incentives for nonprofit organizations, public disclosure programs to make environmental information available to communities and NGOs, or programs granting formal management roles to communitybased organizations-gives biodiversity much stronger backing than civil society organizations can provide unaided. ${ }^{43}$

Financial incentives for conservation have received a great deal of attention from scholars and practitioners alike, but a conservation system dependent on market incentives alone is highly susceptible to the vacillations of the economy. Changes in financial fortunes can lead to the collapse of income-generating projects designed to promote conservation, as has been documented in Peru $^{44}$ and as occurred with nature tourism in East Africa following the 1998 US embassy bombings. ${ }^{45}$ To guard against the vagaries of market conditions, a conservation system should bring together a diverse portfolio of financial interests including, where appropriate, combinations of tourism, hunting and fishing, private concessionaires providing services in protected areas, certified timber operations, harvesters of non-timber forest products, carbon mitigation projects, and other sectors whose incentives for conservation are unlikely to respond equally to a given economic disruption. It is also important to build noneconomic constituencies that can be mobilized in support of conservation and whose motivation to speak out on behalf of these resources is decoupled from market trends. Toward this end, system proponents can link protected areas with municipal water systems, institutionalize educational programs involving site visits by schools, create opportunities for scientific field research, and encourage involvement by local religious organizations, which have been an important voice for conservation in many countries. ${ }^{46}$

Diversity is also an appropriate criterion for the conservation organizations involved, to ensure that the system is not overly susceptible to the fate of a particular organization or charismatic leader. It is also worth involving diverse

42. Steinberg 2005.

43. Steinberg 2005.

44. Yu et al. 1997.

45. Nick Menzies, personal communication.

46. Hsiao et al. 1999. 
government agencies within each level of governance. Although one must be careful to clearly delineate responsibilities among agencies, it is often feasible to involve a water agency, electric power authorities, ministries of tourism and planning, and others that can constitute a more effective political force than can agencies with an exclusive focus on conservation alone. This must be balanced against the potential disadvantages of involving agencies with mandates only partially compatible with the foundational mission of a conservation system. But multi-agency coordination under a lead agency is a common practice in public sector management of problems like disaster response, child protective services, and foreign policy-making, and is consistent with the trend toward strategic environmental assessment aimed at mainstreaming environmental concerns across diverse government agencies.

\section{Testing for Resilience}

As a diagnostic exercise, the resilience of the conservation system can be approximated, and gaps in its protective capacity identified, by arranging meetings with knowledgeable participants who consider a series of hypothetical scenarios that could potentially cause irreversible harm to the resource. Practical methodologies for the conduct of such thought experiments are provided by Wollenberg and by Peterson and colleagues. ${ }^{47}$ Typically taking the form of "what if" questions, potential points of exploration include:

- What if local planners are approached by a well-financed company proposing a project that would significantly harm the resource?

-What if a key piece of national conservation legislation is amended or repealed?

-What if there is a shift in the ruling political party at the local, regional, or national levels?

- What if the tourism market crashes? What if there is a prolonged recession, runaway inflation, or some other disruptive economic development?

-What if a leading local conservation organization were to fold, or if a tireless local conservation leader were no longer available?

- What if the current, principal threat to the resource were mitigated? Are there other threats that might arise in its place?

- What would happen in the event of political instability or widespread civil disruption?

If questions are based on a diverse set of scenarios that are plausible (even at a low probability) given local conditions, the resulting discussion will likely reveal missing components of the system as it stands. During the early stages of design, many de facto "systems" may be remarkably thin-consisting of little 
more than a private reserve, a regulatory agency lacking a local social constituency, or a small and committed organization with shaky organizational foundations. These thought experiments are likely to highlight potential weaknesses, even in systems that participants initially considered fairly robust.

Once weaknesses are identified, the prescriptive stage of the exercise requires adding layers of institutional protection and expanding constituencies through a combination of project design, outreach, coalition building, and other approaches, drawing on participant knowledge of local conditions. To the extent that the mitigation of potential weaknesses requires significant commitments of resources, judgment must be exercised in deciding whether and how to mitigate various risks. The perceived likelihood of a given scenario, as well as its potential for disruption, should enter into participant calculations.

\section{Participation and Coordination}

All of these strategies for thickening the social safety net for biodiversity raise important questions about the feasibility of collective action. However desirable such broad-based coalitions might be from the perspective of resilience, is this achievable given what we know of social coordination problems? To address this question, it is important to note that the degree of additional collaboration implied by a conservation system will vary considerably. In some cases, there may already exist a multi-stakeholder organization that undergoes the evaluative exercise described above and decides to diversify its activities, reaching out to underrepresented political constituencies or advocating for new policies at one or another level of governance. In other cases, the evaluation may inspire the creation of a deliberative body where none existed before. Hence the extent of new collective action, and the associated cost of thickening the constituency for conservation, will vary considerably from case to case. Nevertheless it is important to ask: What incentives do actors have to participate in a conservation system?

The key convening players in such a system will be those whose normative orientation (often embedded in organizational missions) is highly congruous with that of the system mission, or whose material interests are closely tied to the well-being of the valued biological resources it is designed to protect, such as fishing communities whose livelihood is affected by a declining coral reef. But many potentially important constituencies do not fall within this category. Therefore the creation of a conservation system requires what Wijen and Ansari refer to as "collective institutional entrepreneurship." In contrast to cases of institutional change spearheaded by relatively few entrepreneurs, collective institutional entrepreneurship entails "the process of overcoming collective action and achieving sustained collaboration among numerous dispersed actors to create new institutions or transform existing ones." 48 These authors note that collaboration can be promoted by manipulating power configurations (through 
the creation of new alliances or passage of legislation that requires private-sector actors to seek out solutions to social problems), devising incentive structures, or inducing cooperation by framing the issue in terms of mutual identities and interests regarding consensual social norms.

A wide range of incentive structures are available to those looking to bring new constituencies into a conservation system. Examples include sharing information with private sector actors (thereby lowering transaction costs) regarding certification programs, climate mitigation projects, and other arrangements that generate income for those providing ecosystem services, and encouraging their participation in projects funded by governments and international donors. Schneider and colleagues, noting the considerable transaction costs of "developing networks in complex, fragmented, adversarial policy arenas," find that relatively modest amounts of financial and logistical support from a central government program, together with a public participation requirement to qualify for monetary resources, is correlated empirically with stronger local conservation networks. ${ }^{49}$ The broader information function of conservation systems is crucial, and indeed natural resource agency personnel in the United States report that knowledge expansion is among the most valuable benefits that they receive from participation in multi-stakeholder collaborative networks. ${ }^{50}$ The reputational benefits of participation are another potentially important incentive for private sector and governmental actors. Researchers at the World Bank have provided extensive documentation of the importance of community pressure in improving the environmental practices of firms throughout the developing world, ${ }^{51}$ while Tsai reports that local officials in rural China are more likely to provide environmental public goods when subject to community pressure bearing on these officials' moral standing in the community. ${ }^{52}$

In a recent review of cross-sector collaborations, Selsky and Parker report that the motivations for participation in these partnerships are diverse. Organizations may collaborate to achieve resources and competencies they cannot achieve on their own, with a primary interest in maximizing their own organizational interests and preserving autonomy. Alternatively, they may come together either voluntarily or by mandate to address larger social issues or "metaproblems" "that exceed the scope of single organizations ... and tend to fall through the cracks of prevailing institutional arrangements. ${ }^{153}$ Participation in these partnerships allows stakeholders to exert an influence on the outcome.

A significant organizational literature has arisen to identify factors that enable or constrain partnerships across sectors. A review of these findings is well beyond the scope of this article, but key challenges include the distinct motivations of private and nonprofit organizations, the establishment of trust, skilled

\footnotetext{
49. Schneider, Scholz, Lubell, Mindruta, and Edwardsen 2003, 145.

50. Agranoff 2006.

51. See for example Hettige, Huq, Pargal, and Wheeler 1996.

52. Tsai 2007.

53. Selsky and Parker 2005, 852. See also O'Toole 1997; and Bogason and Musso 2006.
} 
facilitation by conveners, the power and autonomy of the nonprofit sector versus other participants, and the ways in which each sector's external stakeholders (stockholders, agency directors, social constituencies, etc.) encourage or discourage their participation in such partnerships. This literature finds that success is possible under a variety of governance structures.

Because conservation systems are complex social arrangements designed to achieve specific goals, a core group should assume responsibility for systemwide coordination to ensure that the valued biological resources are well served by the system as a whole. This coordination function is essential because many of the institutional roles in the system will be filled by actors with only a marginal interest in biodiversity conservation-such as politicians with diverse constituencies, water agencies, firms for which habitat protection is merely a means to profit, and even environmental scientists, many of whom would rather study ecosystem processes than track the latest political developments bearing on an ecosystem's future. This coordinating entity would play a role similar to that of a caseworker in social services, a designated patient advocate in a hospital setting, or a coordination team in emergency response systems. In each case these entities are responsible for a holistic, mission-centered perspective to ensure that the diverse parts of the system are serving their intended function. In a conservation system this role could be played by a council with representation from key participants in the system who, regardless of their organizational affiliation, serve in a capacity in which the priority consideration is the welfare of the valued biological resources at the heart of the system.

\section{Conclusion: Institutional Design as if Politics Mattered}

Political mobilization and institutional design are often cast as distinct phenomena, the province, respectively, of activists and administrators working in their separate spheres. Friedmann rightly identifies technocratic and social mobilization perspectives as two distinct intellectual threads in the development of planning and policy theory. ${ }^{54}$ Yet we also know that institutions selectively mobilize and demobilize social constituencies, distributing and redistributing not only economic resources but also access to decision-making channels, and that social reformers are well aware of this when pursuing their political aims.

When thinking about long-term policy problems, the challenge is to create institutions that mobilize a bias for social well being on time scales that far exceed the day-to-day calculus of people going about their daily lives. Although biodiversity conservation pushes this challenge to an extreme, the foregoing analysis of conservation systems speaks to a larger question that runs across environmental research and practice-why, and under what conditions do people organize to pursue environmental ends, and what role can and do institutions play in this process? As I hope this article demonstrates, to answer this question

54. Friedmann 1987. 
requires that we expand our set of behavioral assumptions at the point of analytic departure-exploring not only economic motivations but the fuller set of drivers that move individuals toward or away from sustainable activities, and the broader set of institutional venues (markets, polling places, families, village meetings, churches, political parties, etc.) through which these motives translate into collective action.

It is striking that the literature on institutional resilience and adaptive management has paid so little attention to political mobilization, especially given that political analysis is a mainstay of scholarship on public management. ${ }^{55}$ There is a need for research that explores more systematically the relationship between political mobilization and institutional design. As a prescriptive exercise, this requires remaining in close conversation with knowledgeable practitioners navigating these very difficult issues on the ground. As an analytic undertaking, it requires mining the fuller institutional tradition, beyond rational actor approaches (and their very considerable contributions) to consider how social rules might constructively channel and reflect the diverse social concerns and capacities bearing on environmental outcomes. We need a clearer understanding of the political underpinnings of resilient environmental institutions, and this is a niche that political science can fill.

\section{References}

Agranoff, Robert. 2006. Inside Collaborative Networks: Ten Lessons for Public Managers. Public Administration Review 66 (1): 56-65.

Agrawal, Arun. 2003. Sustainable Governance of Common-pool Resources: Context, Methods, and Politics. Annual Review of Anthropology 32: 243-262.

Akella, Anita Sundari, and James B. Cannon. 2004. Strengthening the Weakest Links: Strategies for Improving the Enforcement of Environmental Laws Globally. Washington, D.C.: Conservation International, Center for Conservation and Government.

Bogason, Peter, and Juliet A. Musso. 2006. The Democratic Prospects of Network Governance. American Review of Public Administration 36 (1): 3-18.

Bulkeley, Harriet. 2005. Reconfiguring Environmental Governance: Towards a Politics of Scales and Networks. Political Geography 24 (8): 875-902.

Clemens, Elisabeth S., and James M. Cook. 1999. Politics and Institutionalism: Explaining Durability and Change. Annual Review of Sociology 25: 441-466.

Dietz, Thomas, Elinor Ostrom, and Paul C. Stern. 2003. The Struggle to Govern the Commons. Science 302 (5652): 1907-1912.

Downs, Anthony. 1972. Up and Down with Ecology-The "Issue-Attention Cycle." The Public Interest 28 (Summer): 38-50.

Dunlap, Riley E., George H. Gallup, and Alex M. Gallup. 1993. Health of the Planet: Results of a 1992 International Environmental Opinion Survey of Citizens in 24 Nations. Princeton, NJ: The George H. Gallup International Institute.

Fairweather, John R. 1999. Understanding How Farmers Choose between Organic and

55. See, for example, Moore 1995. 
Conventional Production: Results from New Zealand and Policy Implications. Agriculture and Human Values 16 (1): 51-63.

Feldman, Martha S., Anne M. Khademian, Helen Ingram, and Anne S. Schneider. 2006. Ways of Knowing and Inclusive Management Practices. Public Administration Review 66 (1): 89-99.

Folke, Carl. 2006. Resilience: The Emergence of a Perspective for Social-Ecological Systems Analyses. Global Environmental Change 16 (3): 253-267.

Friedmann, John. 1987. Planning in the Public Domain: from Knowledge to Action. Princeton, NJ: Princeton University Press.

Hahn, Thomas, Per Olsson, Carl Folke, and Kristin Johansson. 2006. Trust Building, Knowledge Generation and Organizational Innovations: The Role of a Bridging Organization for Adaptive Comanagement of a Wetland Landscape around Kristianstad, Sweden. Human Ecology 34 (4): 573-592.

Hall, Peter A., and Rosemary C. R. Taylor. 1996. Political Science and the Three New Institutionalisms. Political Studies 44 (5): 936-957.

Hettige, Hemamala, Mainul Huq, Sheoli Pargal, and David Wheeler. 1996. Determinants of Pollution Abatement in Developing Countries: Evidence from South and Southeast Asia. World Development 24 (12): 1891-1904.

Hirschman, Albert O. 1970. Exit, Voice, and Loyalty: Responses to Decline in Firms, Organizations, and States. Cambridge, MA: Harvard University Press.

Hsiao, Hsin-Huang Michael, On-Kwok Lai, Hwa-Jen Liu, Francisco A. Magno, Laura Edles, and Alvin Y. So. 1999. Culture and Asian Styles of Environmental Movements. In Asia's Environmental Movements: Comparative Perspectives, edited by Yokshiu F. Lee and Alvin Y. So, 210-229. Armonk, NY: M.E. Sharpe.

Janssen, Marco A., Michael L. Schoon, Weimao Ke, and Katy Börner. 2006. Scholarly Networks on Resilience, Vulnerability and Adaptation within the Human Dimensions of Global Environmental Change. Global Environmental Change 16 (3): 240-252.

Johnson, K. Norman, et al., eds. 1999. Bioregional Assessments: Science at the Crossroads of Management and Policy. Washington, D.C.: Island Press.

Koontz, Tomas M., and Craig W. Thomas. 2006. What Do We Know and Need to Know about the Environmental Outcomes of Collaborative Management? Public Administration Review 66 (1): 111-121.

Krishna, Anirudh. 2001. Moving from the Stock of Social Capital to the Flow of Benefits: The Role of Agency. World Development 29 (6): 925-938.

Lempert, Robert J. 2000. Robust Strategies for Abating Climate Change. Climatic Change 45 (3-4): 387-401.

Margerum, Richard D. 2008. A Typology of Collaboration Efforts in Environmental Management. Environmental Management 41 (4): 487-500.

Millennium Ecosystem Assessment. 2005. Ecosystems and Human Well-being: Biodiversity Synthesis. Washington, D.C.: World Resources Institute.

Moore, Mark H. 1995. Creating Public Value: Strategic Management in Government. Cambridge, MA: Harvard University Press.

Odum, William E. 1982. Environmental Degradation and the Tyranny of Small Decisions. BioScience 32 (9): 728-729.

Olsson, Per, Carl Folke, and Fikret Berkes. 2004. Adaptive Comanagement for Building Resilience in Social-Ecological Systems. Environmental Management 34 (1): 75-90.

$\mathrm{O}^{\prime}$ Neill, Michael. Forthcoming. Explaining the "Meaning of Greening" in European Poli- 
tics: A Theoretical Overview. In Comparative Environmental Politics, edited by Paul F. Steinberg and Stacy D. VanDeveer. Cambridge, MA: The MIT Press.

Ostrom, Elinor. 1990. Governing the Commons: The Evolution of Institutions for Collective Action. New York: Cambridge University Press.

Ostrom, Elinor, Thomas Dietz, Nives Dolšak, Paul C. Stern, Susan Stonich, and Elke U. Weber, eds. 2002. The Drama of the Commons. Washington, D.C.: National Academy Press.

O'Toole, Laurence. 1997. Treating Networks Seriously: Practical and Research-Based Agendas in Public Administration. Public Administration Review 57 (1): 45-57.

Pearce, David. 1991. An Economic Approach to Saving the Tropical Forests. In Economic Policy towards the Environment, edited by Dieter Helm, 239-262. Oxford: Blackwell Publishers.

Peterson, Garry D., Graeme S. Cumming, and Stephen R. Carpenter. 2003. Scenario Planning: A Tool for Conservation in an Uncertain World. Conservation Biology 17 (2): 358-366.

Press, Daniel. 2002. Saving Open Space: The Politics of Local Preservation in California. Berkeley, CA: University of California Press.

Press, Daniel, Daniel F. Doak, and Paul Steinberg. 1996. The Role of Local Government in the Conservation of Rare Species. Conservation Biology 10 (6): 1538-1548.

Ribot, Jesse. 2002. Democratic Decentralization of Natural Resources: Institutionalizing Popular Participation. Washington, D.C.: World Resources Institute.

Rogers, Everett M. 1995. Diffusion of Innovations, 4th ed. New York: Free Press.

Schneider, Mark, John Scholz, Mark Lubell, Denisa Mindruta, and Matthew Edwardsen. 2003. Building Consensual Institutions: Networks and the National Estuary Program. American Journal of Political Science 47 (1): 143-158.

Selsky, John W., and Barbara Parker. 2005. Cross-Sector Partnerships to Address Social Issues: Challenges to Theory and Practice. Journal of Management 31 (6): 849-873.

Steinberg, Paul F. 1998. Defining the Global Biodiversity Mandate: Implications for International Policy. International Environmental Affairs 10 (2): 113-130. 2001. Environmental Leadership in Developing Countries: Transnational Relations and Biodiversity Policy in Costa Rica and Bolivia. Cambridge, MA: The MIT Press. . 2003 Understanding Policy Change in Developing Countries: The Spheres of Influence Framework. Global Environmental Politics 3 (1): 11-32.

2005. From Public Concern to Policy Effectiveness: Civic Conservation in Developing Countries. Journal of International Wildlife Law and Policy 8: 341-365.

. 2008. But Will It Last? Environmental Governance amid Political Instability. Unpublished paper delivered at the Workshop on Comparative Environmental Politics, UC Berkeley, and forthcoming in Comparative Environmental Politics, edited by Paul F. Steinberg and Stacy D. VanDeveer. Cambridge, MA: The MIT Press.

The World Bank. 2003. World Development Report 2003: Sustainable Development in a Dynamic World. New York: Oxford University Press.

Thomas, Craig W. 2003. Bureaucratic Landscapes: Interagency Cooperation and the Preservation of Biodiversity. Cambridge, MA: The MIT Press.

Tobin, Richard J. 1990. The Expendable Future: U.S. Politics and the Protection of Biological Diversity. Durham, NC: Duke University Press.

Tsai, Lily L. 2007. Solidarity Groups, Informal Accountability, and Local Public Goods Provision in Rural China. American Political Science Review 101 (2): 355-372.

Western, David and R. Michael Wright. 1994. The Background to Community-based 
Conservation. In Natural Connections: Perspectives in Community-based Conservation, edited by David Western et al., 1-12. Washington, DC: Island Press.

Wijen, Frank and Shahzad Ansari. 2007 Overcoming Inaction through Collective Institutional Entrepreneurship: Insights from Regime Theory. Organization Studies 28 (7): 1079-1100.

Wollenberg, Eva, with David Edmunds and Louise Buck. 2000. Anticipating Change: Scenarios As a Tool for Adaptive Forest Management-A Guide. Bogor, Indonesia: Center for International Forestry Research.

Young, Oran R. 1994. International Governance: Protecting the Environment in a Stateless Society. Ithaca, NY: Cornell University Press.

- 2002. The Institutional Dimensions of Environmental Change: Fit, Interplay, and Scale. Cambridge, MA: The MIT Press.

Yu, Douglas W., Thomas Hendrickson, and Ada Castillo. 1997. Ecotourism and Conservation in Amazonian Peru: Short-Term and Long-Term Challenges. Environmental Conservation 24 (2): 130-138. 